East African Medical Journal Vol. 80 No. 7 July 2003

SICKLE CELL DISEASE IN UGANDA: A TIME FOR ACTION

G. R. Serjeant, MD, FRCP, Professor Emeritus, University of the West Indies, 14 Milverton Cresent, Kingston 6 Jamaica and C. M. Ndugwa, MD, FRCP, Department

of Child Health and Paediatrics, Makerere University Medical School, P.O Box 7062, Kampala, Uganda

Request for reprints to: Prof. C.M. Ndugwa, Department of Paediatrics and Child Health, Makerere University Medical School, P.O. Box 7062, Kampala, Uganda

\title{
SICKLE CELL DISEASE IN UGANDA: A TIME FOR ACTION
}

\author{
G. R. SERJEANT and C. M. NDUGWA
}

\begin{abstract}
Objectives: To draw attention to the extent of homozygous sickle cell (SS) disease as a public health problem in Uganda where a mean $20 \%$ frequency of the sickle cell trait implies that $\mathbf{2 5 , 0 0 0}$ babies with SS disease are born each year. To highlight the dangers of applying interventions developed in non-malarial areas to regions where malaria may change the natural history and outcome of sickle cell disease.

Data Sources: The published literature from Africa and from the US and Caribbean in populations of African ancestry.

Study Selection: The world literature especially, that derived from the US, Caribbean, and equatorial Africa.

Data Extraction and synthesis: In non-malarial areas, simple interventions applied early in life have significantly improved survival and the quality of life. Two well documented interventions are pneumococcal prophylaxis and the early parental diagnosis of acute splenic sequestration. The available literature from Africa suggests that neither of these may be appropriate in malarial areas.

Conclusions: Manifestations of SS disease differ in malarial areas and it is questionable whether interventions developed in non-malarial areas apply. There is an urgent need to document the causes of death so that locally appropriate interventions may be developed to improve survival. Equally urgent is the need to define the pattern of clinical problems so that models of care may be evolved for use in malarial areas. Without this knowledge, health care planners will not have the information necessary to develop strategies and limited resources may be inappropriately deployed.
\end{abstract}

\section{INTRODUCTION}

Fifty years ago, the frequency and distribution of the sickle cell trait in Uganda (1-3) revealed marked variations between different tribal groups, 1-4\% in the Karamajong Banyankole, and Bahima, 16-20\% among the Baganda, Etesot, Acholi, and Banyoro, 20-28\% among the Bakiga, Basoga, Bagisu, and Lugbara, and $40 \%$ (the highest frequency described anywhere in the world) among the Baamba. These observations led to conjecture on the anthropological significance of the trait and the migration of people carrying different trait frequencies but also laid the foundation for knowledge on the relationship between the trait and falciparum malaria. Work from Mulago Hospital in Kampala, Uganda documented the reduced parasite density and relative infrequency of malaria in persons with the trait $(4,5)$. The cost of such protection was an average sickle cell trait frequency of $20 \%$ and homozygous sickle cell (SS) affecting 1-2\% of births, prompting Trowell et al (6) in 1957 to comment "That a paediatric problem of this magnitude existed in Africa has only recently been realised" In Uganda's current population of 25 million, approximately 25,000 babies are born with SS disease each year yet there are few comprehensive studies of clinical features in Uganda
$(6,7)$. The fate of these children is largely unknown although indirect evidence suggests that $70-80 \%$ die by the age of two years and malaria is likely to be a major determinant of mortality. Interventions designed in non-malarial areas (810), have significantly improved survival (11), but preliminary data cast doubt on their appropriateness in malarial areas. There is an urgent need to document the clinical course, causes and age of death of patients with sickle cell disease in malarial areas and provide the knowledge essential for health care planners to develop appropriate services and interventions.

This review addresses some of the factors known to influence expression of sickle cell disease elsewhere and attempts to highlight important areas of ignorance and research opportunities in Uganda. It is hoped that it will act as a stimulus to research and also inform health care personnel on the extent of the problem and the need to improve management and services for the disease.

Genotypes of sickle cell disease: The available data indicate that SS disease is the dominant and maybe the only form of sickle cell disease in East Africa. Haemoglobin $\mathrm{C}(\mathrm{HbC})$ with a prevalence of $20 \%$ in parts of Ghana and Burkina Faso and 3-5\% in Nigeria does not occur in East 
Africa except in persons of West African origin and the double heterozygous sickle cell-haemoglobin C(SC) would not be expected to occur. The genes for beta ${ }^{+}$, and beta 0 thalassaemia which occur in $1.0 \%$ and $0.5 \%$ of Jamaicans of West African ancestry (12) give rise to sickle cell-beta ${ }^{+}$ and sickle cell-beta ${ }^{0}$ thalassaemia but the frequency of these conditions in East Africa is unknown. Sickle cellbeta thalassaemia most commonly results in $20-30 \% \mathrm{HbA}$ and a mild clinical condition easily detectable on routine haemoglobin electrophoresis whereas sickle cell-beta 0 thalassaemia produces only $\mathrm{HbS}, \mathrm{HbF}$, and $\mathrm{HbA}_{2}$, similar to the pattern observed in SS disease, and the diagnosis rests on family studies, microcytic red cells (MCV<70fl) and raised levels of $\mathrm{HbA}_{2},(>4.5 \%)$. If these conditions do occur, they are likely to be uncommon and almost all sickle cell disease in East Africa may be assumed to be SS disease. The existence of only one major genotype simplifies research and removes an important variable in clinical course in populations of West African origin.

Molecular variation: The $\mathrm{HbS}$ mutation has arisen independently in several geographical locations. Structural variations in the DNA molecule flanking the beta globin gene, referred to as the beta globin haplotypes, are named after the areas where they were first described i.e Senegal, Benin and Bantu (13-17). The Senegal haplotype occurs on the Atlantic coast of West Africa the Benin haplotype in Central West Africa especially Ghana, Nigeria, and Cotê D'lvoire and the Bantu or Central African Republic haplotype in the Democratic Republic of Congo, the Central African Republic, Angola and Kenya (18). A fourth Asian haplotype characterises the $\mathrm{HbS}$ gene in the Eastern Province of Saudi Arabia (19,20), and in Central India(21), where the DNA structure differs from those encountered in Africa. Because the Benin haplotype predominates among sickle cell populations in Europe and the Americas, most of the available haematological and clinical data are from this haplotype. Although there are no direct data, Ugandan patients are assumed to have the Bantu haplotype and Uganda offers an opportunity to describe its clinical and haematological features.

Other factors with a genetic basis which ameliorate severity in patients of west African origin, include high levels of fetal haemoglobin $(\mathrm{HbF})$ and deletional alpha thalassaemia (22). Heterozygous alpha thalassaemia occurs in $35 \%$ and homozygosity in $4 \%$ of Jamaicans of West African ancestry. Anecdotal evidence suggests that both high $\mathrm{HbF}$ levels and alpha thalassaemia are common in surviving SS patients in Uganda which, if confirmed, affords a model for investigating the mechanism of such effects.

The impact of malaria: Most published work on sickle cell disease derives from non-malarial areas of the US, Caribbean, and Europe, and caution is needed in extrapolating the findings to areas where malaria is common. Falciparum malaria confers a survival advantage on the sickle cell trait, but although data in SS disease are conflicting $(23,24)$ it is undoubtedly a major contributor to both the morbidity and mortality of the disease. The mechanism is unclear and it is debated whether deaths occur from malaria itself or from precipitating the symptoms of sickle cell disease. The markedly shortened red cell life of 10-12 days typical of SS disease will be aggravated by the additional haemolysis of acute malaria, the fever would promote dehydration with precipitation of dactylitis or painful crises, and increased endothelial adhesion of red and white cells provides a further. Malaria may also change the natural history of splenic structure and function in SS disease contributing to the clinical impression that splenomegaly persists more frequently in Ugandan SS children. The interaction of falciparum malaria and SS disease presents many important questions and challenges which can best be answered in areas such as equatorial Africa where both diseases co-exist. What is the most effective malarial prophylaxis for patients with SS disease? Is chloroquinerophylaxis feasible in an area where perhaps $70 \%$ of malarial parasites are chloroquine resistant, or are impregnated bed nets more realistic? Does effective prophylaxis hinder the development of natural immunity rendering patients particularly susceptible if prophylaxis ceases? Should patients be allowed to develop active immunity by prompt treatment of malarial episodes or are the risks of this approach too high? These very practical questions are essential to the management of sickle cell disease in Uganda.

The spleen: This is central to much of the early pathology in SS disease with the abnormal red cells damaging the filtering mechanism and rendering patients prone to blood infections. In non-malarial areas, splenic function is lost early and a gradual progressive fibrosis culminates in a small shrunken splenic remnant (autosplenectomy), although episodes of acute splenic sequestration (ASS) or sustained sequestration (hypersplenism) may be superimposed.

Acute splenic sequestration, with acute enlargement of the spleen, typically $2-4 \mathrm{~cm}$ below the costal margin, is associated with haemoglobin falls of $3 g$ or more and raised reticulocytes counts. It was a common cause of morbidity and death in Jamaica where teaching the mother its diagnosis now leads to earlier presentation and a reduction in mortality from this complication by $90 \%$ (10). The prevalence of ASS, whether its natural history is modified by malaria, and whether parental education in its early detection would have the same beneficial effect is unknown in Uganda.

Chronic hypersplenism is characterised by marked splenomegaly, sequestration of red cells and a new haematological equilibrium with $\mathrm{Hb}$ levels of $3-5 \mathrm{~g} / \mathrm{dl}$ and reticulocytes of $20-30 \%(25)$. Extreme bone marrow hypertrophy increases metabolic demands and consumes protein and calories normally needed for growth. Height velocity falls, children are stunted and a growth spurt follows relief of hypersplenism by splenectomy $(26,27)$. Morbidity of hypersplenism also results from the increased cardiovascular work associated with the low haemoglobin and an increased mortality from haemorrhage, superimposed 
acute sequestration, or coincident aplastic crisis. Management in the past has been based on intermittent transfusion while awaiting progression of splenic fibrosis avoiding splenectomy because of concerns over removing any remaining splenic immune function. It is now known that the risks of infection or death are no higher in splenectomized SS patients than in matched SS controls without splenectomy (28) and surgery is increasingly advocated if spontaneous resolution does not occur after an observation period of 3-6 months. There is a clinical impression that hyperslenism is common in Uganda and associated with singnificant morbidity. This requires formal confirmation and study.

Overwhelming infection: In non-malarial areas, the loss of splenic filtering capacity leads to a greater risk of, septicaemia in SS disease especially in the first two years of life $(29,30)$ and falling rapidly thereafter. Streptococcus Pneumoniae $(31,32)$ has been the dominant organism in non-malarial areas and pneumococcal prophylaxis with penicilin $(8,9)$ has become routine clinical care commencing at four months and continuing until four years at least. This increased risk of Streptococcus pneumoniae septicaemia does not characterise SS disease in all areas. In the Eastern Province of Saudi Arabia, splenic function persists longer $(33,34)$ and Streptococcus pneumoniae is a less frequent cause of septicaemia (35) than Salmonella and other gram-negative organisms.

Data on causes of bacteraemia in SS disease from Africa have reached conflicting conclusions. In the Democratic Republic of the Congo, Streptococcus pneumoniaewas the most frequent isolate from bacteraemic SS patients $(36,37)$ and this organism was found in the blood of all the eight cases with 'pneumonia' in northern Nigeria (38). However, three other Nigerian studies (39-41) have shown a paucity of Streptococcus pneumoniae. None occurred among 19 bacteraemias in Lagos(39), one among 54 bacteraemias in Benin City (40) and none among 304 children admitted with acute illness in Kaduna (41) although this organism was found in the CSF of three children. In Uganda there was also a dearth of Streptococcus pneumoniae as a cause of septicaemia (Monica Etima 2002, personal communication). In the five African studies from Nigeria and Uganda, the most common causes of bacteraemia were Klebsiella, Streptococcus aureus, and Salmonella species. The virtual absence of Streptococcus pneumoniae in these studies is unexplained but could be due to the widespread use of across-the-counter antibiotics, death before presentation to hospital in patients septicaemic with Streptococcus pneumoniae or the intriguing possibility that malaria encourages persistence of splenic function in patients with SS disease (41). The hypothesis of greatest concern is that children with Streptococcus pneumoniae septicaemia die before reaching hospital although this seems intrinsically unlikely (three children with Streptococcus pneumoniae in the CSF reached hospital in Kaduna). In this context a randomised trial of pneumococcal prophylaxis with death as an endpoint would be useful, since fewer deaths in those receiving prophylaxis could justify its use regardless of the cause of death. Currently the data on the frequency of Streptococcus pneumoniae as a cause of septicaemia in SS patients in Africa do not justify the use of pneumococcal prophylaxis and Ministries of Health with limited resources and the large numbers of patients, will require incontrovertible evidence to institute such a policy.

Documenting the age and cause of early mortality: The greatest challenge for Uganda remains the charting of the natural history of sickle cell disease from childhood. Mortality is generally greatest in the first year of life and the inferred high early mortality in Uganda requires a study based upon the intensive follow up of children detected by newborn screening to document the principal causes of death. This information is essential to the design of simple interventions to prevent deaths and to health care planning throughout regions where SS disease and falciparum malaria coincide. Such a study should have the greatest priority at this time, and from it, answers to the other questions will flow. These should address the optimal mode of malaria prophylaxis, the role for antibiotic prophylaxis, the optimal management of acute and chronic splenic sequestration, and the charting of the natural history of the disease.

Sickle cell disease in Uganda is a major public health problem with poor visibility and low, awareness, a situation that will persist if patients continue to be hidden away in families. Declaration of the disease is the first step in establishing the frequency of the problem and the need for clinical services. The disease cannot yet be cured but elsewhere simple interventions have improved not only survival (11), but also the quality of life. These interventions may not be appropriate for Uganda but others will be evolved which can also improve the outcome of the disease. Sickle cell disease is not an inevitable cause of death. Median survival of SS patients in the US now exceeds 40 years (42), and in Jamaica 50 years (43). The oldest patient known to the Sickle cell Clinic at Mulago Hospital is 73 years. The outlook should be much brighter but the disease must receive greater attention both from affected families and from the health care planners. In 1957, Trowell et al (6), noted "The present study reveals many differences between the pattern of the disease as seen in Central Africa and that recorded in West Africa and America. The most important differences lie in its early age of onset, rapid rate of evolution, and high mortality in infancy in Central Africa". Nearly 50 years later, something should be done to document and change these perceptions.

\section{ACKNOWLEDGEMENTS}

Professor Serjeant acknowledges the support of the Department for International Development East Africa, Uganda.

\section{REFERENCES}

1. Lehmann, H. and Raper, A.B. Distribution of the sickle-cell trait in Uganda, and its ethnological significance. Nature. 1949; 164:494-495. 
2. Lehmann, H. and Raper, A.B. Maintenance of high sickling rate in an African community. Brit. Med. J. 1956; 2:333-336.

3. Allison, A.C. The distribution of the sickle-cell trait in East Africa and elsewhere, and its apparent relationship to the incidence of subtertian malaria. Trans. Roy. Soc. Trop. Med. Hyg. 1954; 48:312-318.

4. Raper, A.B. Malaria and the sickling trait. Brit. Med. J. 1955; 1: 1186-1189.

5. Raper, A.B. Sickling in relation to morbidity from malaria and other diseases. Brit. Med. J. 1956 1: 965-966.

6. Trowell, H.C., Raper, A.B. and Welbourn, H.F. The natural history of homozygous sickle-cell anaemia in Central Africa. Quart. J. Med. 1957; 26:401-422.

7. Trowell, H.C. Sickle cell anaemia. East Afr. Med. J. 1945; 22:34-45.

8. John, A.B., Ramlal, A., Jackson, H., Maude, G.H., Waight S. A. and Serjeant, G.R. Prevention of pneumococcal infection in children with homozygous sickle cell disease. Brit. Med. J. 1984; 288:1567-1570.

9. Gaston, M.H., Verter, J.I., Woods, G., et al. Prophylaxis with oral penicillin in children with sickle cell anemia. N. Engl. J. Med. 1986; 314:1593-1599.

10. Emond, A.M., Collis, R., Darvill, D., Maude, G., and Serjeant, G.R. Acute splenic sequestration in homozygous sickle cell disease; natural history and management. J. Pediatr. 1985; 107:201-206.

11. Lee, A., Thomas, P., Cupidore, L., Serjeant, B. and Serjeant, G. Improved survival in homozygous sickle cell disease: lessons from a cohort study. Brit. Med. J. 1995; 311: 160-162.

12. Serjeant, G.R., Serjeant, B.E., Forbes, M.,et al. Haemoglobin gene frequencies in the Jamaican population: a study of 100,000 newborns. Brit. J. Haematol. 1986; 64:253-262.

13. Pagnier, J., Mears, J.G., Dunda-Belkhodja, O., et al. Evidence for the multicentric origin of the sickle cell haemoglobin gene in Africa. Proc. Natl. Acad. Sci. USA. 1984; 81:1771-1773.

14. Nagel, R.L., Erlingsson, S., Fabry, M.E., et al. The Senegal DNA haplotype is associated with the amelioration of anemia in Africa-American sickle cell anemia patients. Blood. 1991; 77:1371-1375

15. Nagel, R.L., Fabry, M.E., Pagnier, J., et al. Hematologically and genetically distinct forms of sickle cell anemia in Africa. N. Engl. J. Med. 1985; 312:880-884.

16. Nagel, R.L., Rao, S.K., Dunda-Belkohdja, O., et al. The hematological characteristics of sickle cell anemia bearing the Bantu haplotype: the relationship between $\mathrm{G} \gamma$ and $\mathrm{HbF}$ level. Blood. 1987; 69:1026-1030.

17. Chebloune, Y., Pagnier, J., Trabuchet, G.,et al. Structural analysis of the 5 flanking region of the B-globin gene in African sickle cell anemia patients: further evidence for three origins of the sickle cell mutation in Africa. Proc. Natl. Acad. Sci.1988; 85:4431-4435.

18. Ojwang, P.J., Ogada, T., Beris, P., et al. Haplotypes and Bglobin gene analyses in sickle cell anaemia patients from Kenya. Brit. J. Haematol. 1987; 65:211-215.

19. El-Hazmi, M.A.F. Beta globin gene haplotypes in the Saudi sickle cell anaemia patients. Human Heredity. 1990; 40: 177-186.

20. Padmos, M.A., Roberts, G.T., Sackey, K., et al. Two different forms of homozygous sickle cell disease occur in Saudi Arabia. Brit. J. Haematology. 1991; 79:93-98.

21. Kulozik, A.E., Wainscoat, J.S., Serjeant, G.R., et al. Geographical survey of $\beta^{S}$-globin gene haplotypes: evidence for an independent Asian origin of the sickle-cell mutation. Ann. J. Hum. Genet. 1986; 39:239-244.

22. Dozy, A.M., Kan, Y.W., Embury, S.H., et al. Alpha gene organisation in Blacks precludes the severe form of $\alpha$ thalassaemia. Nature. 1979; 280: 605-607.
23. Adeloye, A., Luzzatto, L. and Edington, G.M. Severe malarial infection in a patient with sickle-cell anaemia. Brit. Med. J. 1971; 2:445-446.

24. Aluoch, J.R. Higher resistance to Plasmodium falciparum infection in patients with homozygous sickle cell disease in western Kenya. Trop. Med. Internat. Health. 1997; 2:568571.

25. Mallouh, A.A. and Salamah, M.M. Hypersplenism in homozygous sickle-cell disease in Saudi Arabia. Ann. Trop. Paediatr. 1985; 5:143-146.

26. Singhal, A., Thomas, P., Kearney, T., Venugopal, S. and Serjeant, G. Acceleration in linear growth after splenectomy for hypersplenism in homozygous sickle cell disease. Arch. Dis. Child. 1995; 72:227-229.

27. Badaloo, A.V., Singhal, A., Forrester, T.E., Serjeant, G.R. and Jackson. A.A. The effect of splenectomy for hypersplenism on whole body protein turnover, resting metabolic rate and growth in sickle cell disease. Eur. J. Clin. Nutr. 1996; 50: 672-675.

28. Wright, J.G., Hambleton, I.R., Thomas, P.W., et al. Postsplenectomy course in homozygous sickle cell disease. J. Pediatr. 1999; 134:304-309.

29. Zarkowsky, H.S., Gallagher, D., Gill, F.M., et al. Bacteremia in sickle hemoglobinopathies. J. Pediatr. 1986; 109:579-585.

30. Magnus, S.A., Hambleton, I.R., Moosdeen, F. and Serjeant, G.R. Recurrent infections in homozygous sickle cell disease. Arch. Dis. Child. 1999; 80:537-541.

31. Robinson, M.G. and Watson, R.J. Pneumococcal meningitis in sickle-cell anaemia. N. Engl. J. Med. 1966; 274:1006-1008.

32. Barrett-Connor, E. Bacterial infection and sickle cell anemia. Medicine. 1971; 50:97-112.

33. Al-Awamy, B., Wilson, W.A. and Pearson, H.A. Splenic function in sickle cell disease in the Eastern Province of Saudi Arabia. J. Pediatr. 1984; 104:714-717.

34. Mallouh, A.A., Burke, G.M., Salamah, M. and Ahmad, M.S Splenic function in Saudi children with sickle cell disease. Ann. Trop. Paediatr. 1984; 4:87-91.

35. Mallouh, A.A. and Salamah, M.M. Pattern of bacterial infections in homozygous sickle cell disease. Am. J. Dis. Child. 1985; 139:820-822.

36. Eeckels, R., Gatti, F. and Renoirte, A.M. Abnormal distribution of haemoglobin genotypes in Negro children with severe bacterial infections (Letter). Nature. 1967; 216:382.

37. Eeckels, R., Gatti, F., Vandepitte, J. and Debroise, A. Susceptibility to severe infections in children with sicklecell haemoglobinopathies. Proceedings of the 5th International Congress on Infectious Disease, Vienna. 1970; 267-271.

38. Maharajan, R., Fleming, A.F. and Egler, L.J. Pattern of infections among patients with sickle-cell anaemia requiring hospital admissions. Nig. J. Paediatr. 1983; 10: 13-17.

39. Akinyanju, O.O. and Johnson, A.O. Acute illness in Nigerian children with sickle cell anaemia. Ann. Trop. Paediat. 1987; 7:181-186.

40. Okuonghae, H.O., Nwankwo, M.U. and Offor, E.C. Pattern of bacteraemia in febrile children with sickle cell anaemia. Ann. Trop. Paediatr. 1993; 13: 55-64.

41. Akuse, R.M. Variation in the pattern of bacterial infection in patients with sickle cell disease requiring admission. J. Trop. Pediatr. 1996; 42:318-323.

42. Platt, O.S., Brambilla, B.J., Rosse, W.F., et al. Mortality in sickle cell disease. Life expectancy and risk factors for early death. N. EngI. J. Med. 1994; 330:1639-1644.

43. Wierenga, K.J.J., Hambleton, I.R. and Lewis, N.A. Survival estimates for patients with homozygous sickle-cell disease in Jamaica: a clinic-based population study. Lancet. 2001; 357:680-683. 